\title{
Decrement in Cellular Iron and Reactive Oxygen Species, and Improvement of Insulin Secretion in a Pancreatic Cell Line Using Green Tea Extract
}

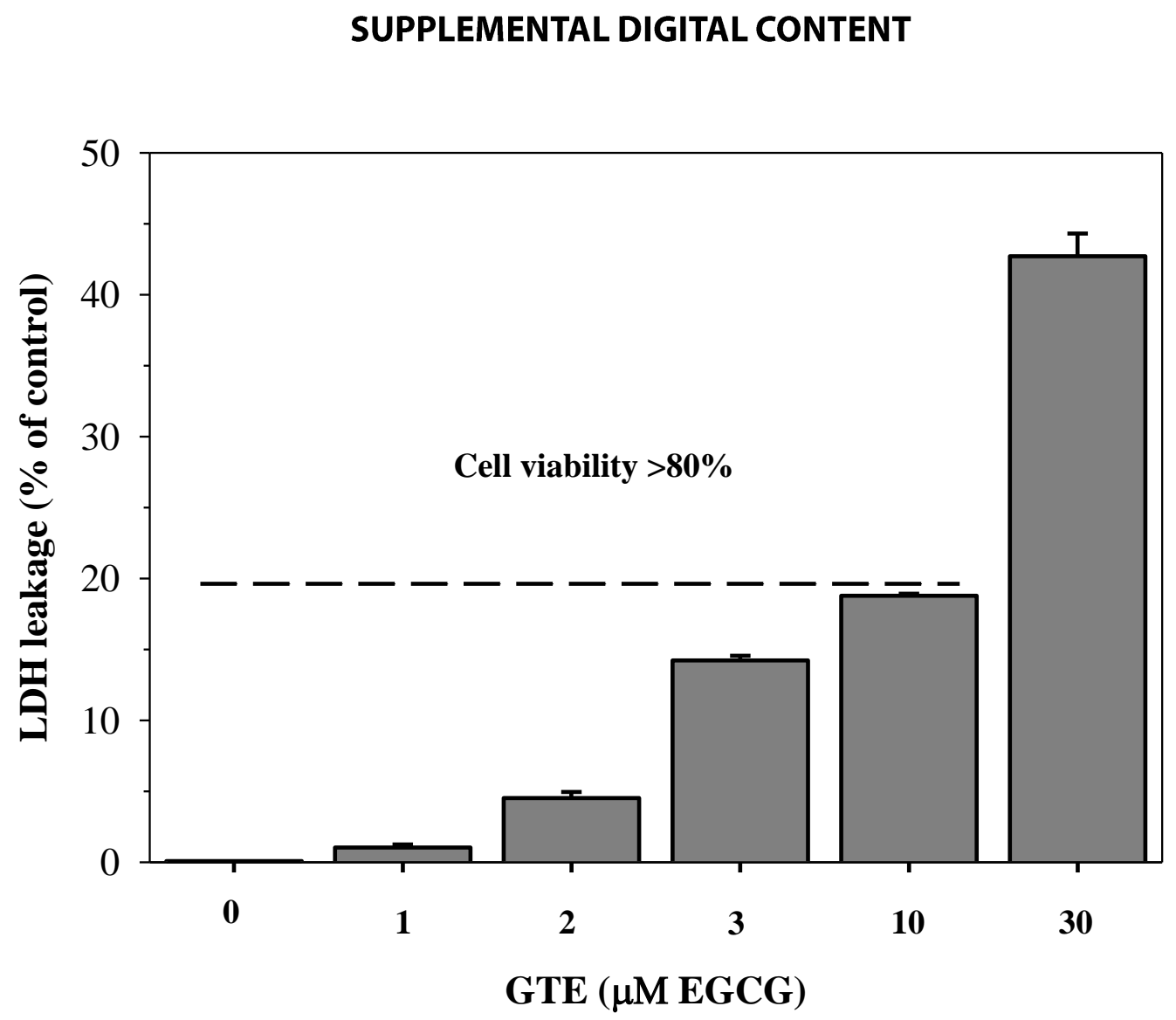

SUPPLEMENTAL FIGURE 1. Leakage of LDH from RINm5F cells incubated with complete medium containing GTE (1-30 mM EGCG). Data obtained from three independent experiments are expressed as mean \pm SEM. 